\title{
Histological and Immunohistochemical Study of Titanium Dioxide Nanoparticle Effect on the Rat Renal Cortex and the Possible Protective Role of Lycopene
}

\author{
Original \\ Article \\ Zainab M Altayeb ${ }^{1}$, Abeer M. El-Mahalaway ${ }^{2}$ and Maysara M. Salem ${ }^{3}$ \\ ${ }^{1}$ Department of Histology and Cell Biology, Faculty of Medicine, Helwan University \\ ${ }^{2,3}$ Department of Histology and Cell Biology, Faculty of Medicine, Benha University.
}

\begin{abstract}
Introduction: Titanium dioxide nanoparticles (TNPs) have a wide range of applications in industry, medicine and environmental technology. Nowadays, TNPs have raised researcher's concerns on their toxicity. Lycopene is a dietary carotenoid having a potent antioxidant effect.

Aim: To evaluate the effect of TNPs on the structure of renal cortex of rats and to assess the possible protective effect of lycopene against TNPs nephrotoxicity.

Material and methods: Forty five adult male rats were divided into four groups. Group I (the control group) included 20 rats, which were divided equally into 4 subgroups. Subgroup IA was the negative control, Subgroup IB given one $\mathrm{ml}$ corn oil by gastric tube, Subgroup IC given one ml distilled water intraperitoneally (i.p) and Subgroup ID given one $\mathrm{ml}$ corn oil by gastric tube and one $\mathrm{ml}$ distilled water (i.p). Group II included 5 rats received a daily dose of $10 \mathrm{mg} / \mathrm{kg}$ body weight (BW) of lycopene by gastric tube for 4 weeks. Group III included 10 rats injected with $150 \mathrm{mg} / \mathrm{kg}$ BW (i.p.) of TNPs daily for 4 weeks. Group IV included 10 rats received both TNPs and lycopene at the same aforementioned doses for 4 weeks. Kidney specimens were prepared and sections were stained with hematoxylin and eosin and Masson's trichrome. Immunohistochemical detection of desmin, anti-proliferating cell nuclear antigen (PCNA) and caspase-3 was done.

Results: Our results revealed that group II had similar findings nearly as group I. Group III showed congested dilated glomerular capillaries. The convoluted tubules showed exfoliation of some lining epithelial cells and degenerative changes. There were interstitial haemorrhage, mononuclear cell infiltration and increase in collagen fibers around degenerated convoluted tubules and glomeruli. A significant increase in desmin-expression in the glomerular cells was observed. Besides, there were significant increases of PCNA positive nuclear and caspase-3 cytoplasmic reactions in renal tubular cells. Group IV revealed amelioration of these changes.
\end{abstract}

Conclusion: Lycopene protected rat's renal cortex against TNPs nephrotoxicity.

Key Words: Kidney, lycopene, titanium dioxide nanoparticle toxicity, caspase-3, desmin, PCNA.

Received: 16 January 2017, Accepted: 30 April 2017

Corresponding Author: Maysara Salem, Tel.: +201064470443, E-mail: maysara.m.salem@gmail.com

ISSN: 1110-0559, March 2017, Vol. 40, No. 1

\section{INTRODUCTION}

Nanoparticles (NPs) are wide spread nowadays all over the world and the exposure to these materials is expected through several mechanisms. Exposure might take place throughout environmental discharge into water, air or soil during the industrial process, disposition of manufacturing or engine combustion or research waste. NPs could be liberated from machining, sanding or disposing of nanomaterial-containing products. Also, exposure might happen during biologic elimination from a primary target or throughout device wear ${ }^{[1]}$.
The kidney is one of the vital organs in the body, excreting of body waste products and drugs through highly specialized cells located in renal nephrons. Kidney diseases can lead to life-threatening sequels. The kidney functions can be altered by many environmental contaminants, chemicals and drugs ${ }^{[2]}$. The wide variety of potential applications of NPs in electronic, optical and biomedical fields attracts many scientists to give much attention for more researches on nanotechnology ${ }^{[3]}$.

Silicon, titanium and iron are the most well known metallic oxide NPs used in industries. The production 
and widespread use of NPs in various fields affect health through environmental and occupational exposures and consumer products ${ }^{[4]}$. Titanium dioxide $\left(\mathrm{TiO}_{2}\right)$, an odorless and noncombustible white powder can crystallize in three structures as rutile, brookite and anatase. $\mathrm{TiO}_{2}$ is a semiconducting chemically inert material that displays photocatalytic activity when subjected to light ${ }^{[5]}$.

Titanium dioxide nanoparticles are one of the famous widely produced NPs in the world due to their wonderful physicochemical characters, as biocompatibility, resistance to corrosion, their low cost, whitening, photocatalysis and ease of obtaining at nano sizes. They are one of the most five NPs used in industry and have several beneficial uses in sciences as cosmetics, pharmaceuticals, medicine, neutralizing and destroying the cancer cells, engineering, water treatment, purification and filtration of gases, especially air and decolorization ${ }^{[6-8]}$.

Nowadays, several studies have revealed that TNPs are toxic accumulate to human organs as kidneys, liver, lungs, spleen, central nervous system and heart and give rise to oxidative stress. They are absorbed into the body by ingestion, inhalation, and dermal penetration, and are distributed to important organs as kidneys, liver, lungs, brain, and lymphatic organs ${ }^{[9-13]}$

The kidney is considered to be one of the vital organs susceptible to the impact of TNPs as a result of their filtration through uriniferous tubules ${ }^{[6]}$. Nowadays, much attention has been directed to the use of dietary antioxidants of natural products for prevention and treatment of such drawbacks and may have a significant role in keeping and safeguard health ${ }^{[14]}$.

Carotenoids have expanded implementation as antioxidants in dietary supplements because they are safe and cheap, also restore the optimal balance and strengthen the endogenous antioxidant defenses ${ }^{[15]}$.

Lycopene has been reported as one of the potent antioxidants among dietary carotenoids found in plenty amount in watermelon, tomatoes, pink grapefruit, papaya and pink guava. The human body is unable to synthesize carotenoids, so diet is the only source of these compounds for body tissues and organs ${ }^{[16-18]}$.

Lycopene has several pharmacological and biological actions such as anti-inflammatory, antioxidant, anti-fibrotic and anti-apoptotic activities. It inhibits proliferation of several types of cancer cells, including those of lung, breast, colorectal, endometrium and prostate. It also hinder smalignant transformation of brain cells in rodents ${ }^{[19,20]}$.

Moreover, it may relieve chronic diseases such as eye disease, coronary heart diseases, male infertility, osteoporosis and inflammation. Also, it acts as a protector against chemical-induced hepatic and renal damage ${ }^{[17,19]}$.
The aim of this study is to evaluate the effect of TNPs and the possible protective role of lycopene on the adult male albino rats renal cortices.

\section{MATERIAL AND METHODS}

Forty five adult male albino rats of weight range 180-210 gm were used. The animals were obtained from the animal house, Moshtohor Faculty of Veterinary Medicine, Benha University. The animals were housed in special cages and were maintained under standard laboratory conditions and fed standard balanced diet and water ad libitum. The animal experimental protocol was approved by the Institutional Animal Care Committee.

\section{Experimental design}

Rats were divided into four groups.

Group I (control group): included 20 rats, were further divided into 4 equal subgroups as follows: .

Subgroup IA: 5 rats kept as a negative control with no treatment.

Subgroup IB: 5 rats received $1 \mathrm{ml}$ corn oil (vehicle for lycopene) by gastric tube daily for 4 weeks.

Subgroup IC: 5 rats were injected i.p. with $1 \mathrm{ml}$ distilled water (vehicle for TNPs) daily for 4 weeks.

Subgroup ID: 5 rats were given one $\mathrm{ml}$ corn oil by gastric tube and one $\mathrm{ml}$ distilled water (i.p) daily for 4 weeks.

Group II (lycopene group): This group included 5 rats received lycopene at a dose of $10 \mathrm{mg} / \mathrm{kg}$ body weight dissolved in corn oil as a vehicle orally by gastric tube daily for 4 weeks ${ }^{[21]}$.

Group III (TNPs group): 10 rats injected i.p. with TNPs at a dose of $150 \mathrm{mg} / \mathrm{kg}$ body weight suspended in $1 \mathrm{ml}$ distilled water daily for 4 weeks ${ }^{[6]}$.

Group IV (TNPs and lycopene): 10 rats received TNPs together with lycopene at the same time and doses as the above groups for 4 weeks.

\section{Chemicals}

Titanium dioxide nanoparticles (TNPs) anatase, $<25$ $\mathrm{nm}$, powder form and lycopene powder were purchased from Sigma Chemical Co (St. Louis, Missouri, USA). 


\section{Histological and immunohistochemical study}

At the end of the experiment, the rats were anesthetized with diethyl ether and dissected. Fresh specimens of right renal cortex were collected and fixed immediately in $10 \%$ neutral buffered formalin. Paraffin sections $(5 \mu \mathrm{m}$ in thickness) were prepared and stained with Masson's trichrome to detect collagen fibers and $H \& E$ to verify histological details ${ }^{[22]}$.

\section{Immunohistochemical assessment}

1- Immunohistochemical staining for detection of desmin

The primary monoclonal antibody was the mouse anti-desmin monoclonal antibody (Lab Vision Corp, Neomarkers, Inc /Lab Vision, Fremont, California, USA). The positive reaction was brown color in the cytoplasm.

2- Immunohistochemical staining for detection of antiproliferating cell nuclear antigen (PCNA)

The primary monoclonal antibody was anti PCNA IgG antibody (Santa Cruz Biotechnology Inc., Santa Cruz, CA, USA). The cellular site of the reaction was brown color in nuclei of the cells.

3- Immunohistochemical staining for detection of caspase-3

The primary monoclonal antibody was the mouse monoclonal primary antibody to caspase-3 (Ab-7, Mouse Mab. MS.). The cellular reaction appeared as brownish cytoplasm of the cells.

Immunohistochemical study was conducted using the avidin - biotin peroxidase method. Briefly, $5 \mu \mathrm{m}$ sections were deparaffinized, rehydrated, rinsed in tap water, and embedded in $3 \% \mathrm{H}_{2} \mathrm{O}_{2}$ for $10 \mathrm{~min}$ to block endogenous peroxidase.

The sections were treated initially with $2 \%$ trypsin at $37^{\circ} \mathrm{C}$ for $10 \mathrm{~min}$ in order to increase the sensitivity of the immune-peroxidase staining method. Sections were immersed in an antigen retrieval solution $(10 \mathrm{mmol} / \mathrm{l}$ sodium citrate buffer, $\mathrm{pH}$ 6) and subjected to heatinduced antigen retrieval for $20 \mathrm{~min}$ in a microwave. Non-specific protein binding was blocked by a blocking solution (phosphate buffered saline (PBS) and 10\% normal goat serum). The slides were incubated with the diluted primary antibody using PBS for $30 \mathrm{~min}$. Drops of streptavidin peroxidase were added to the slide, left for $20 \mathrm{~min}$, then washed with PBS for $5 \mathrm{~min}$. The chromogen Diaminobenzidine (Dakopatts, Glostrup, Denmark) was added to slides, thereafter the slides were washed with distilled water. Finally, the sections were counterstained with Harris's hematoxylin $(\mathrm{H})$, dehydrated, and cover slipped. Negative controls were run routinely in parallel by omitting the primary antibody. The binding of the primary antibody was visualized using the commercial avidinbiotin-peroxidase detection kit (Dako) according to the manufacturer's instructions. Staining was completed with DAB Chromogen for 1-2 min, after which the slides were counterstained with Harris's hematoxylin, dehydrated, rendered transparent with xylene, cover slipped and observed under a light microscope.

\section{Morphometric study}

The mean area percentage of collagen fibers deposition, desmin immunostaining, PCNA immunoreactivity and caspase-3 immunostaining were quantified in five images of non-overlapping fields in sections of each rat's renal cortex using Image-Pro Plus program version 6.0 (Media Cybernetics Inc., Bethesda, Maryland, USA).

\section{Statistical analysis}

All the data collected from the experiment was recorded and analyzed using IBM SPSS Statistics software for Windows, Version 20 (IBM Corp., Armonk, NY, USA). Paired t-test was used to compare differences in group IV (TNPs and lycopene group) with group III (TNPs group). In each test, the data was expressed as the mean $(\mathrm{M})$ value, standard deviation (SD) and differences were considered to be significant at $P<0.01$.

\section{RESULTS}

\section{Histological results}

\section{Hematoxylin and eosin stain}

Group I: There was no histological difference between subgroups IA, IB, IC and ID. The renal cortex of the rats of this group revealed normal histological appearance of renal (Malpighian) corpuscles which were formed of glomerular capillaries and Bowman's capsules. The Bowman's capsule was formed of two layers, the outer parietal layer which was formed of simple squamous epithelium and the inner visceral layer formed of special cells called podocytes. The two layers were separated by urinary space. Proximal convoluted tubules had narrow lumina. They were numerous and lined with simple truncated cubical (pyramidal) cells with basal spherical nuclei. Distal convoluted tubules had wide lumina. They were less numerous and were lined with simple cubical cells with central or apical spherical nuclei (Fig. 1).

Group II: The structures of the renal cortex of rats of this group were similar to that of the rats of group I.

Group III: Revealed histological changes in the form of congested and dilated glomerular capillaries, 
epithelial cell flattening and cytoplasmic vacuolation of some tubular cells, intratubular cell debris, exfoliation and extrusion of some epithelial tubular cells, apparent luminal dilatation and some tubular cells had pyknotic nuclei. There were mononuclear cell infiltrations among degenerated tubules and renal corpuscles and interstitial haemorrhage (Figs 2 and 3).

Group IV: Revealed most of the renal glomeruli and tubules more or less normal, but few tubules revealed cytoplasmic vacuolations in their lining cells (Fig. 4).

\section{Masson's trichrome stain:}

Group I (the control group): The renal cortex of the control rat revealed minimal amount of collagen fibers around the renal tubules, capillary tuft of glomeruli and Bowman's capsules (Fig. 5).

Group II: No noticeable changes were seen in the distribution of collagen fibers in the renal cortex in this group in comparison with group I.

Group III: Revealed an increase of collagen fibers around Bowman's capsules, glomerular capillary loops, the convoluted tubules (Fig. 6) and around mononuclear cell infiltrations (Fig. 7).

Group IV: Revealed few collagen fibers around convoluted tubules and glomeruli (Fig. 8).

\section{Immunohistochemical staining of desmin:}

Group I: The renal cortex of the rats of this group showed a negative desmin immunostaining in the renal glomeruli (Fig. 9).

Group II: No noticeable changes were seen to desmin immunostaining in this group in comparison with the group I.

Group III: Revealed positive desmin immune reaction in the renal glomerulus (Fig. 10).

Group IV: Revealed apparent decrease of desmin immune reaction in the renal glomerulus compared to group III (Fig. 11).

\section{Immunohistochemical staining of PCNA:}

Group I: The renal cortex of the rats of this group revealed faint positive PCNA immune reaction in renal tubular cells (Fig. 12).

Group II: No noticeable changes were seen to PCNA immunoreactivity in this group in comparison with the group I.

Group III: Revealed increase positive PCNA immune reaction in renal tubular cells (Fig. 13). PCNA-positive proliferating mononuclear cells in interstitial tissue were also noticed (Fig. 14).

Group IV: Revealed apparent decrease positive PCNA immune-reactivity in renal tubular cells (Fig. 15).

\section{Immunohistochemical staining of caspase-3:}

Group I: The renal cortex of the rats of this group revealed negative caspase- 3 immune reaction of the tubular cell cytoplasm (Fig. 16).

Group II: No noticeable changes were seen to caspase-3 immunostaining in this group in comparison with the group I.

Group III: Revealed highly expressed caspase-3 reaction in the cytoplasm of the tubular cells (Fig. 17).

Group IV: Revealed apparent minimally expressed caspase-3 reaction in the cytoplasm of the tubular cells (Fig. 18).

\section{Morphometric results}

The mean area $\%$ of collagen fibers deposition, desmin immunostaining, PCNA immunoreactivity and caspase-3 immunostaining for all groups was represented in tables (1- 4) and histograms (1- 4). There was a significant decrease $(P<0.01)$ in collagen fibers deposition, desmin immunostaining, PCNA immunoreactivity and caspase-3 immunostaining in group IV compared with group III. 
Table 1: Showing the mean area $\%$ and \pm SD of collagen fibers deposition in all experimental groups. Group IV compared with group III.

\begin{tabular}{|c|c|c|c|c|}
\hline & Group I & Group II & Group III & Group IV \\
\hline Mean area $\%$ & $8.04 \%$ & $6.11 \%$ & $24.46 \%$ & $11.47 \%$ \\
\hline $\mathrm{SD} \pm$ & 1.1382 & 0.8146 & 1.1185 & 0.8176 \\
\hline$P$ value & & & & 0.000 \\
\hline $\begin{array}{l}\text { Significance (S) } \\
\text { at } P<0.01\end{array}$ & & & & S \\
\hline
\end{tabular}

$\mathrm{SD}=$ Standard deviation

$\mathrm{S}=$ Significant

Table 2: Showing the mean area $\%$ and \pm SD of desmin immunostaining in all experimental groups. Group IV compared with group III.

\begin{tabular}{|c|c|c|c|c|}
\hline & Group I & Group II & Group III & Group V \\
\hline Mean area $\%$ & $0 \%$ & $0 \%$ & $18.7 \%$ & $1.9 \%$ \\
\hline $\mathrm{SD} \pm$ & 0 & 0 & 1.1186 & 0.6179 \\
\hline$P$ value & & & & 0.000 \\
\hline Significance (S) at $P<0.01$ & & & & $\mathrm{~S}$ \\
\hline \multicolumn{5}{|l|}{$\begin{array}{l}\mathrm{SD}=\text { Standard deviation. } \\
\mathrm{S}=\text { Significant }\end{array}$} \\
\hline & Group I & Group II & Group III & Group V \\
\hline Mean area $\%$ & $0.24 \%$ & $0.30 \%$ & $1.52 \%$ & $0.54 \%$ \\
\hline $\mathrm{SD} \pm$ & 0.0419 & 0.0597 & 0.3247 & 0.1468 \\
\hline$P$ value & & & & 0.000 \\
\hline Significance (S) at $P<0.01$ & & & & $\mathrm{~S}$ \\
\hline
\end{tabular}

$\mathrm{SD}=$ Standard deviation .

$\mathrm{S}=$ Significant 
Table 4: Showing the mean area $\%$ and \pm SD of caspase-3 immunostaining in all experimental groups. Group IV compared with group III.

\begin{tabular}{|c|c|c|c|c|}
\hline & Group I & Group II & Group III & Group V \\
\hline Mean area $\%$ & $0 \%$ & $0 \%$ & $10.01 \%$ & $0.8 \%$ \\
\hline $\mathrm{SD} \pm$ & 0 & 0 & 1.8332 & 0.4001 \\
\hline$P$ value & & & & 0.000 \\
\hline Significance (S) at $P<0.01$ & & & & $\mathrm{~S}$ \\
\hline
\end{tabular}

$\mathrm{SD}=$ Standard deviation .

$\mathrm{S}=$ Significant

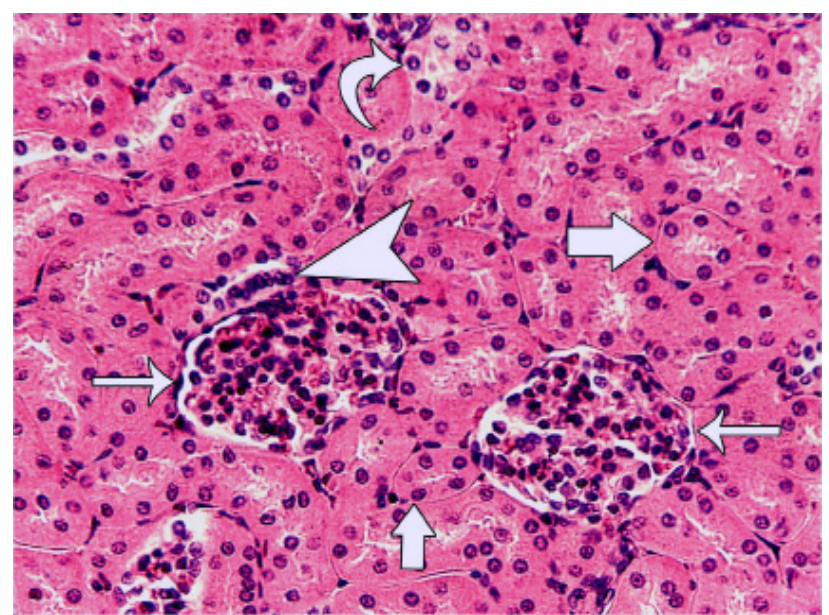

Fig. 1: A photomicrograph of a section in the renal cortex from control group showing renal glomeruli $(\uparrow)$, proximal convoluted tubules (thick arrows), distal convoluted tubule (bent arrow), and macula densa (arrow head).

$(\mathrm{H} \& \mathrm{E} \times 400)$.

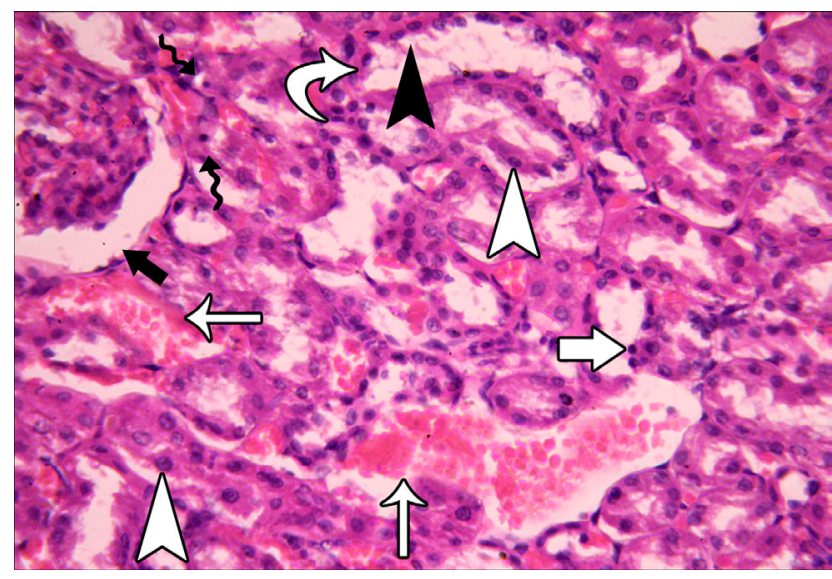

Fig. 2: A photomicrograph of a section in the renal cortex from group III showing interstitial hemorrhage $(\uparrow)$, exfoliation of some lining epithelial cells of some tubules (white arrow heads), flattening of the epithelial lining of some tubules (black arrow head) with apparent tubular dilatation (bent arrow). Some tubular cells show pyknotic nuclei (thick white arrow) and vacuolated cells with pyknotic nuclei (zigzag arrows). Notice: widening of the Bowman's space (thick black arrow).

$(\mathrm{H} \& \mathrm{E} \times 400)$.

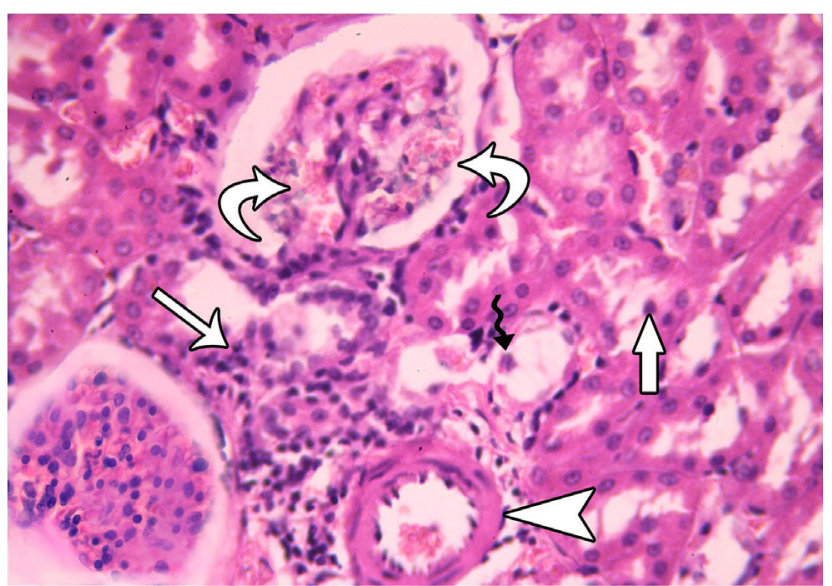

Fig. 3: A photomicrograph of a section in the renal cortex from group III showing mononuclear cell infiltrations between degenerated tubule and renal corpuscles $(\uparrow)$. Dilated congested glomerular capillaries (bent arrows), pyknotic exfoliated nuclei (thick arrow), intratubular cell debris (zigzag arrow) and an arteriole can be seen (arrow head).

$(\mathrm{H} \& \mathrm{E} \times 400)$

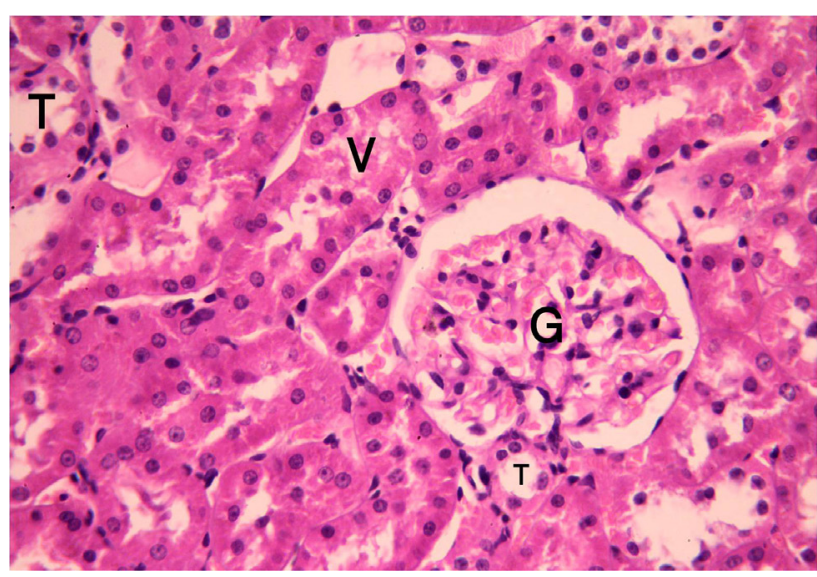

Fig. 4: A photomicrograph of a section in the renal cortex from group IV showing glomerulus $(\mathrm{G})$ and most the convoluted tubules were apparently normal $(\mathrm{T})$. Few tubules have cytoplasmic vacuolations in their lining cells $(\mathrm{V})$.

$(\mathrm{H} \& \mathrm{E} \times 400)$. 


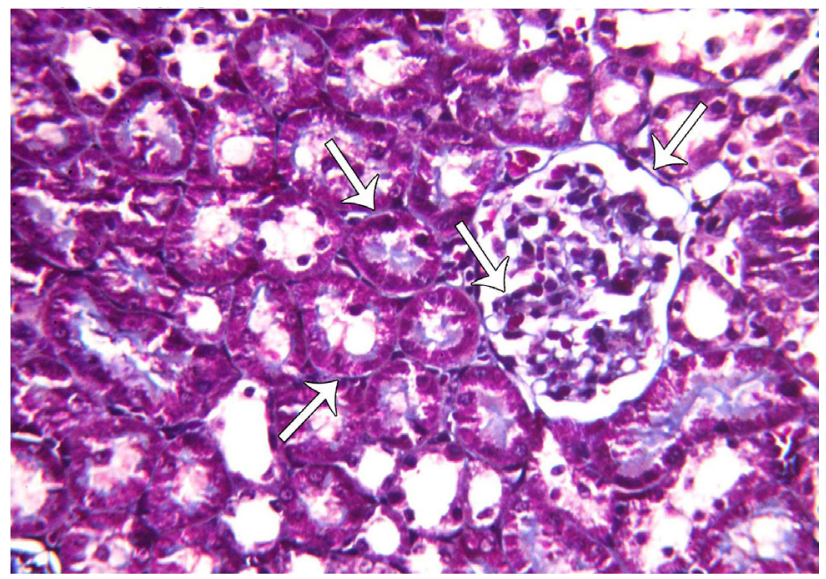

Fig. 5: A photomicrograph of a section in the renal cortex from control group showing minimal amount of collagen around renal tubules, Bowman's capsules and capillary tuft of glomerulus $(\uparrow)$.

(Masson's Trichrome $\times 400$ ).

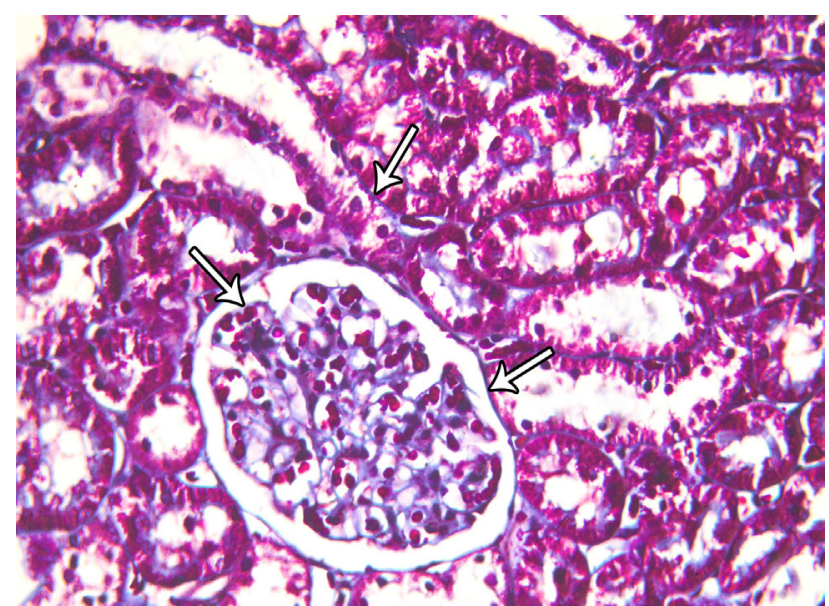

Fig. 6: A photomicrograph of a section in the renal cortex from group III showing an increase of the collagen fibers around convoluted tubules, Bowman's capsule and capillary loops of glomerulus ( $\uparrow$.

(Masson's Trichrome $\times 400$ ).

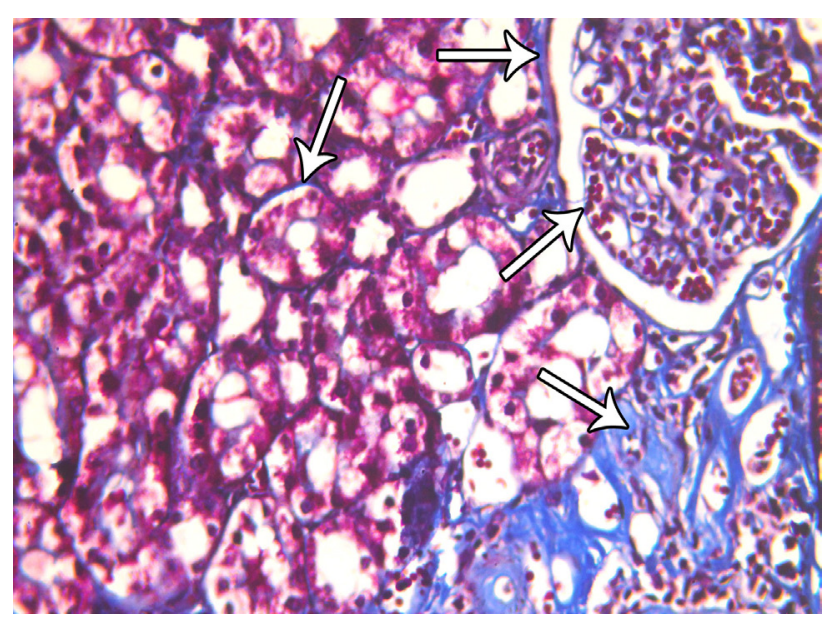

Fig. 7: A photomicrograph of a section in the renal cortex from group III showing marked increase of the collagen fibers around mononuclear cell infiltrations, convoluted tubules, Bowman's capsules and congested capillary loops of glomerulus ( $\uparrow$ ).

(Masson's Trichrome $\times 400$ ).

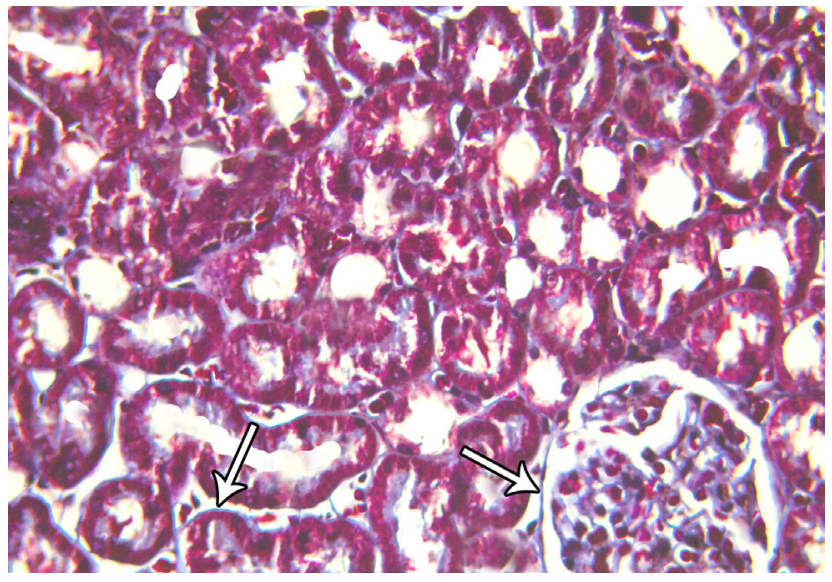

Fig. 8: A photomicrograph of a section in the renal cortex from group IV showing few collagen fibers around glomerulus and convoluted tubules $(\uparrow)$.

(Masson's Trichrome $\times 400$ ).

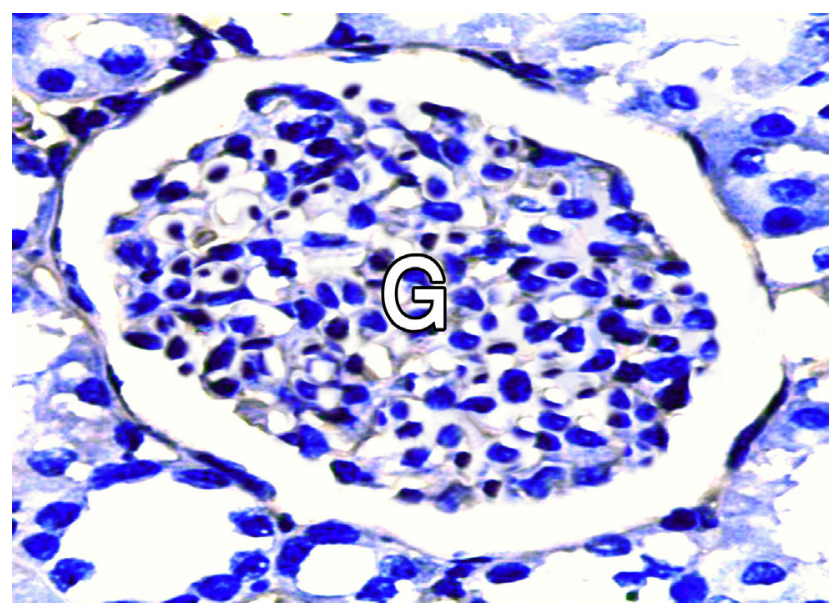

Fig. 9: A photomicrograph of a section in the renal cortex from control group showing negative desmin immunostaining in the renal glomerular cells.

(Immunostaining for desmin and $\mathrm{H}$ as a counter stain $\times 630$ ).

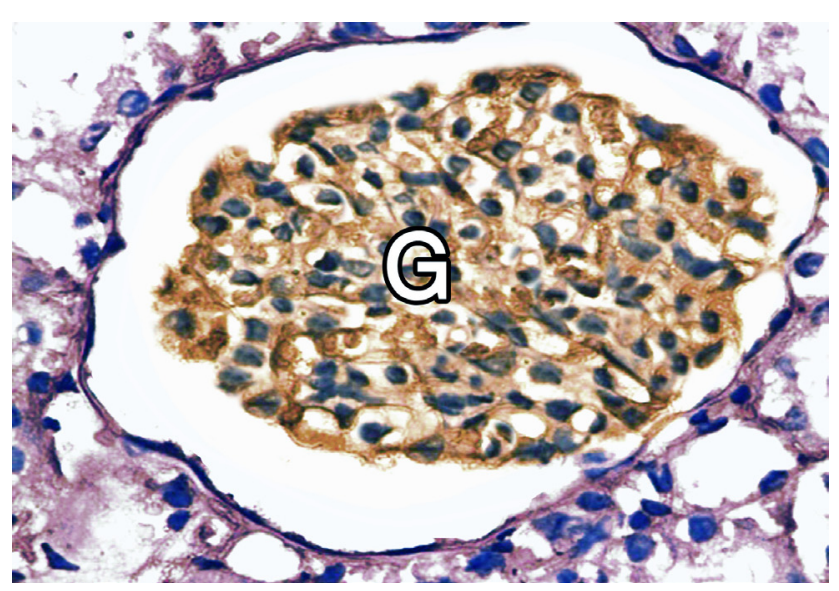

Fig. 10: A photomicrograph of a section in the renal cortex from group III showing positive desmin immunostaining in the renal glomerular cells $(\mathrm{G})$.

(Immunostaining for desmin and $\mathrm{H}$ as a counter stain $\times 630$ ). 


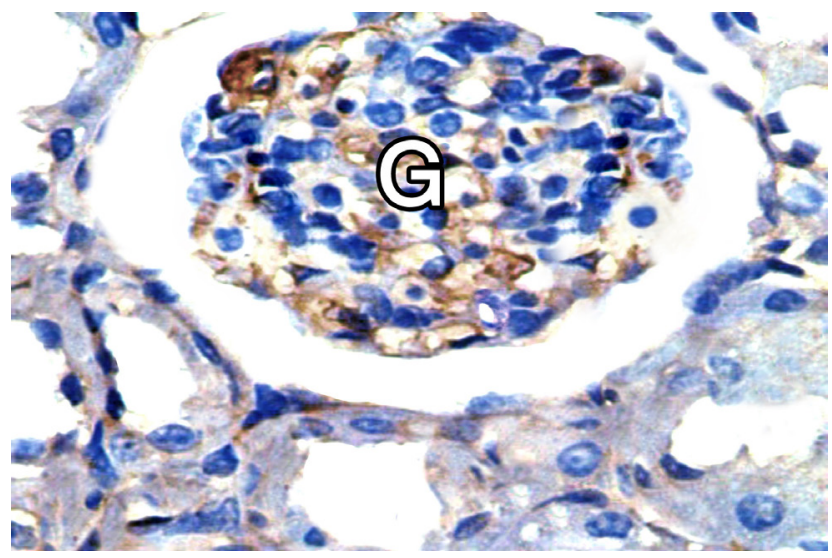

Fig. 11: A photomicrograph of a section in the renal cortex from group IV showing decrease of desmin immunostaining in the renal glomerulus $(\mathrm{G})$.

(Immunostaining for desmin and $\mathrm{H}$ as a counter stain $\times 630$ ).

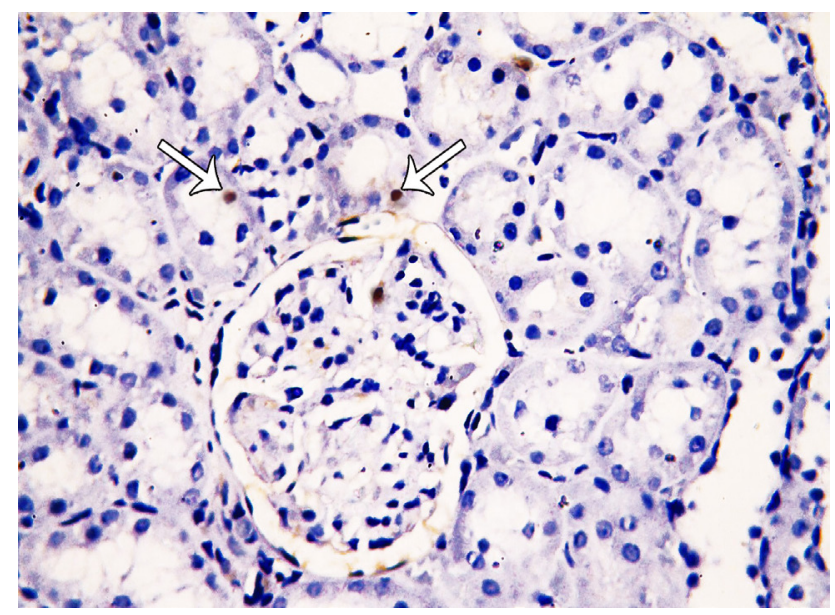

Fig. 12: A photomicrograph of a section in the renal cortex from control group showing a few number of positive PCNA immunoreactivity in renal tubular cells $(\uparrow)$.

(Immunostaining for PCNA and $\mathrm{H}$ as a counter stain $\times 400$ ).

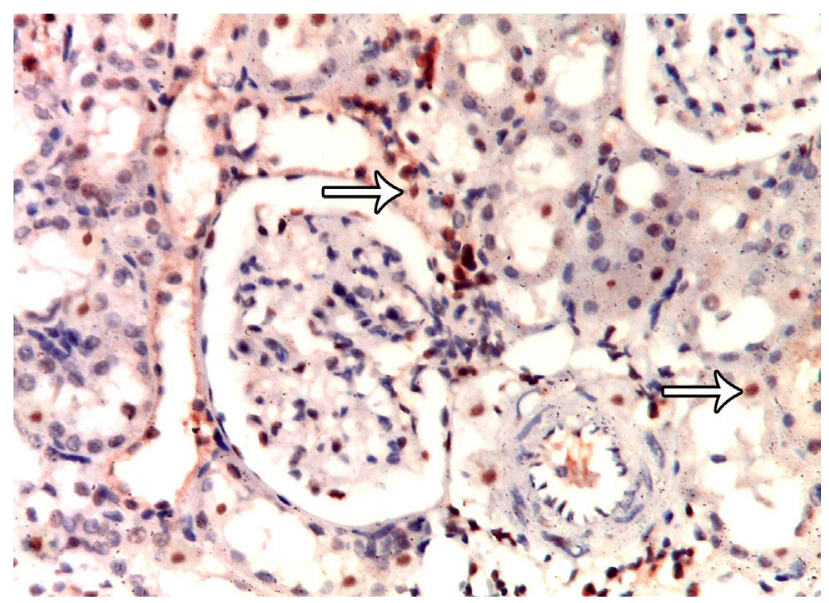

Fig. 13: A photomicrograph of a section in the renal cortex from group III showing apparent increase positive PCNA immunoreactivity in renal tubular cells $(\uparrow)$.

(Immunostaining for PCNA and $\mathrm{H}$ as a counter stain $\times 400$ ).

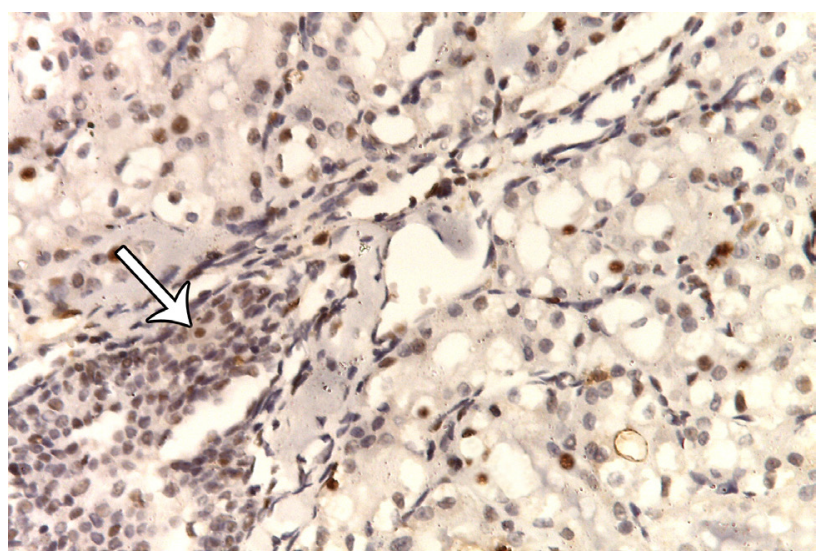

Fig. 14: A photomicrograph of a section in the renal cortex from group III showing apparent increase positive PCNA immunoreactivity in renal tubular cells and PCNA-positive proliferating mononuclear cells in interstitial tissue $(\uparrow)$.

(Immunostaining for PCNA and $\mathrm{H}$ as a counter stain $\times 400$ ).

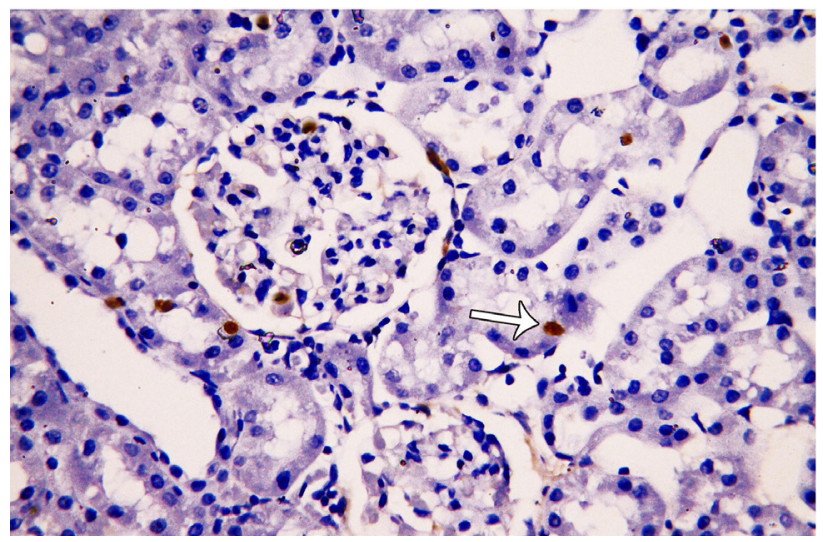

Fig. 15: A photomicrograph of a section in the renal cortex from group IV showing apparent decrease positive PCNA immunoreactivity in renal tubular cells $(\uparrow)$.

(Immunostaining for PCNA and $\mathrm{H}$ as a counter stain $\times 400$ ).

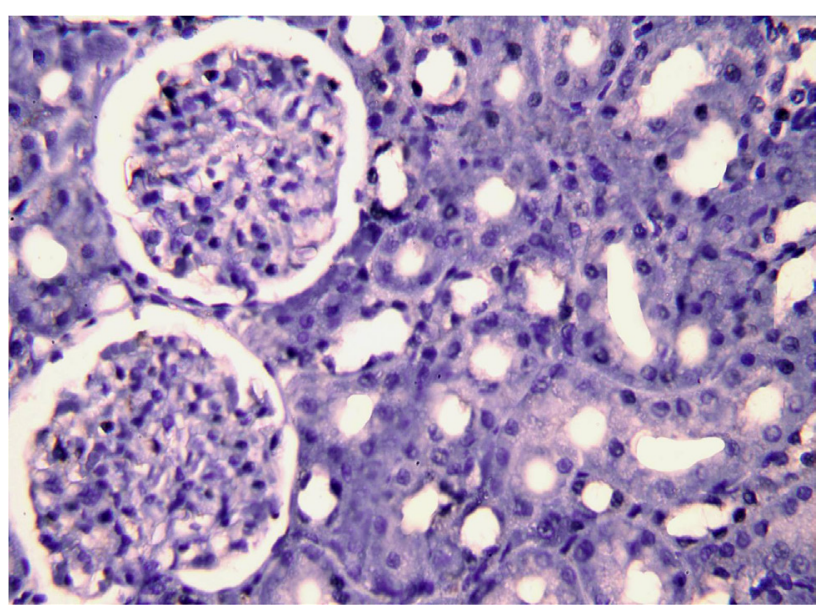

Fig. 16: A photomicrograph of a section in the renal cortex from control group showing negative caspase-3 immunostaining of the tubular cell cytoplasm.

(Immunostaining for caspase- 3 and $\mathrm{H}$ as a counter stain $\times 400$ ). 


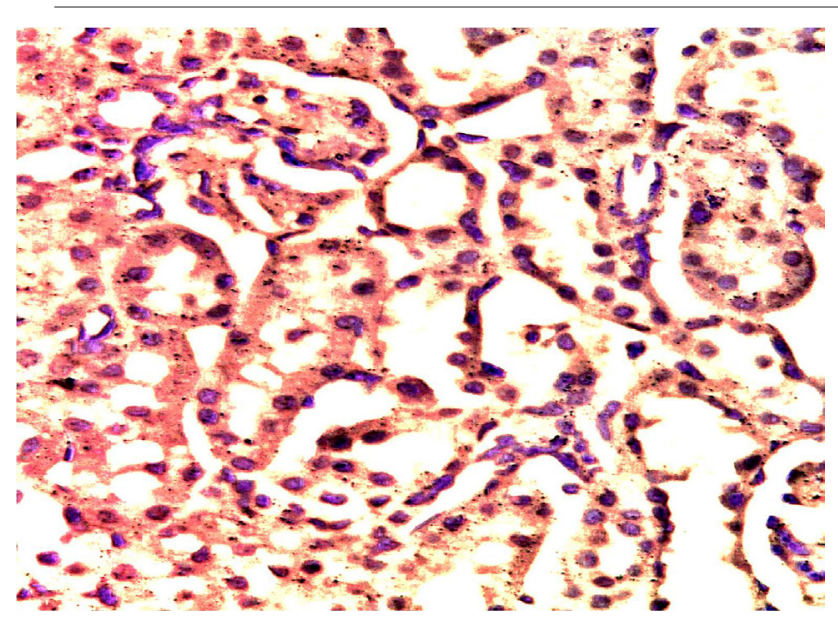

Fig. 17: A photomicrograph of a section in the renal cortex from group III showing highly expressed caspase- 3 reaction in the cytoplasm of the tubular cells.

(Immunostaining for caspase- 3 and $\mathrm{H}$ as a counter stain $\times 400$ ).

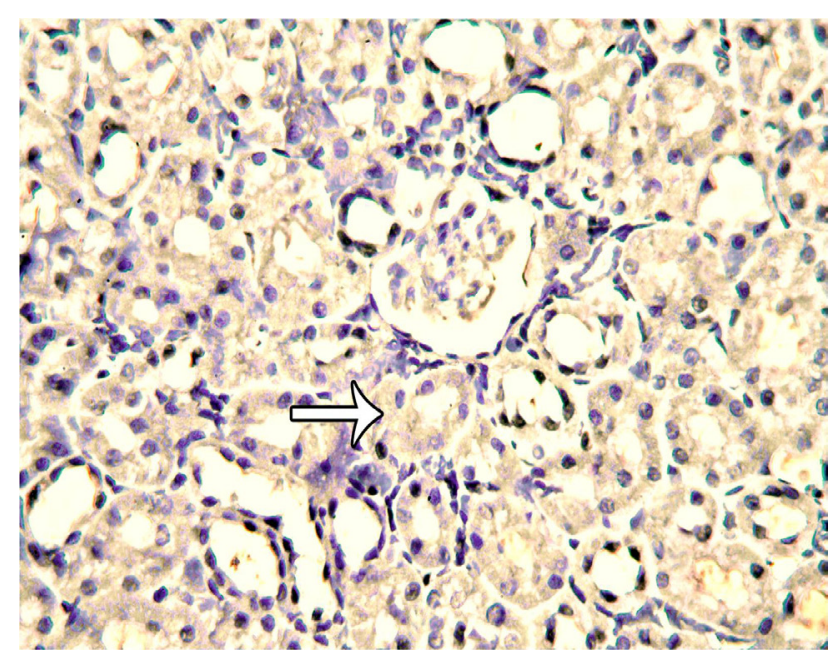

Fig. 18: A photomicrograph of a section in the renal cortex from group IV showing minimally expressed caspase-3 reaction in the cytoplasm of the tubular cells $(\uparrow)$.

(Immunostaining for caspase- 3 and $\mathrm{H}$ as a counter stain $\times 400$ ).

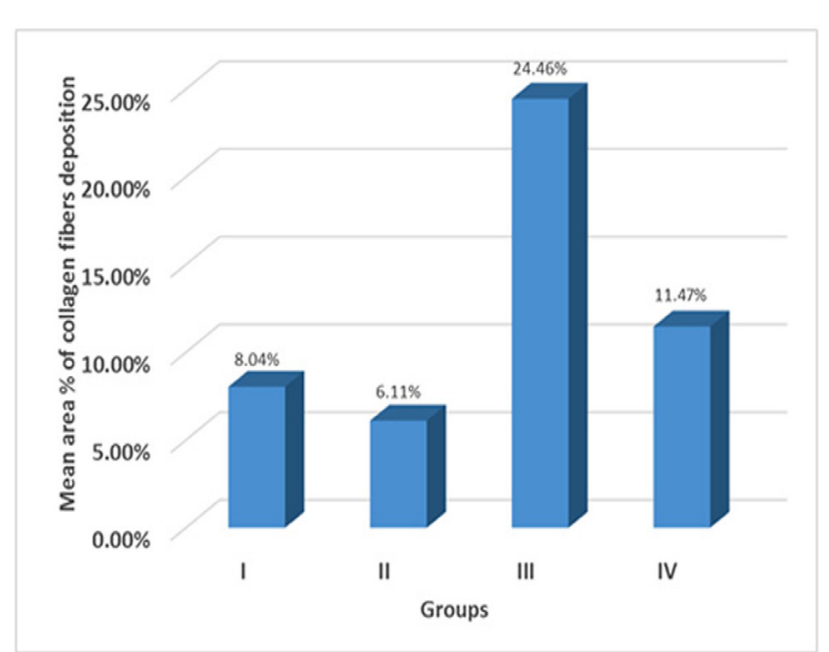

Histogram 1: Showing the mean area \% of collagen fibers deposition in all experimental groups.

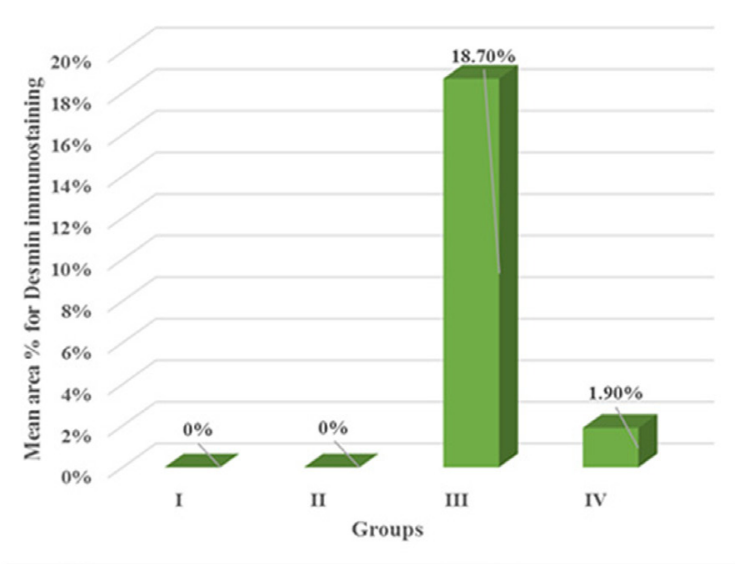

Histogram 2: Showing the mean area $\%$ of desmin immunostaining in all experimental groups.

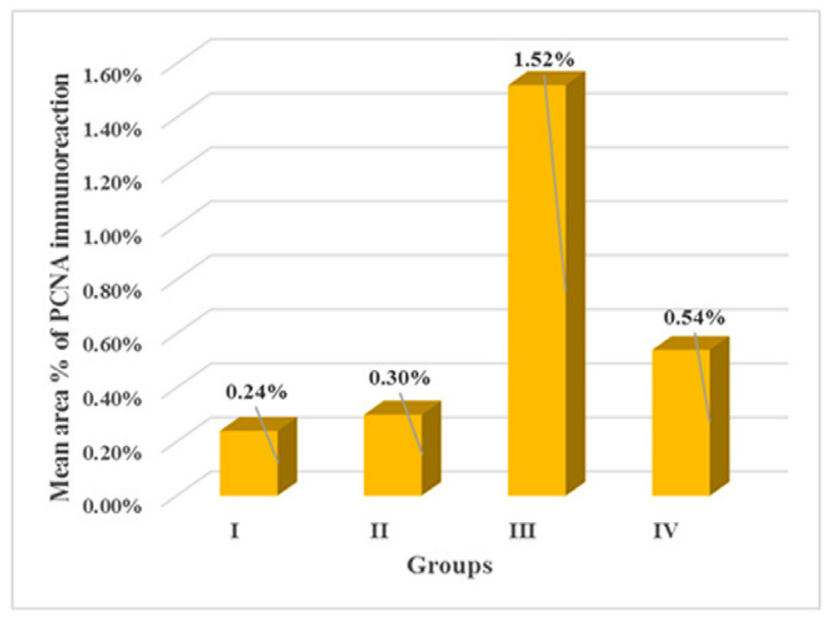

Histogram 3: Showing the mean area $\%$ of PCNA immunoreactivity in all experimental groups.

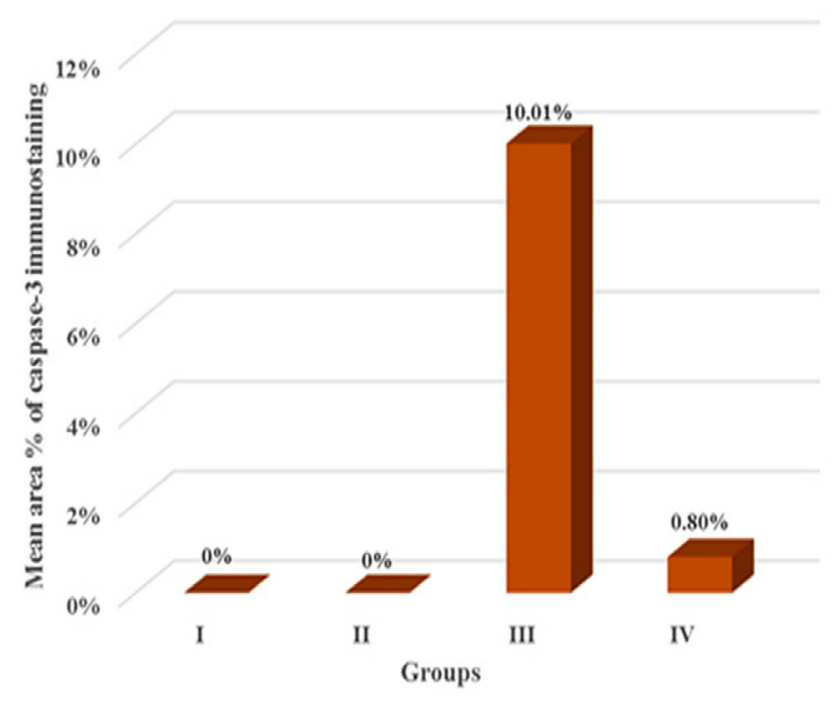

Histogram 4: Showing the mean area \% of caspase-3 immunostaining in all experimental groups. 


\section{DISCUSSION}

Nanoparticles have been used in several applications as science, technology, medicine and many other fields. Among the many types of NPs, the $\mathrm{TiO}_{2}$ which is one of the most produced NPs in the world, have attracted particular technological and scientific interest because of their unique chemical and physical characters and also their influence on human health and the environment ${ }^{[23,24]}$. However, the present researches about the toxicities of NPs, both in naturally occurring particles and in engineered nanomaterials, are highly increasing ${ }^{[25]}$.

In this study titanium dioxide was injected by i.p route. The drug absorption by i.p injection is good and rapid because of the intensive blood and lymph vessels in the peritoneum beside its large surface area, thus the drug easily reached to the circulation. Moreover, injection can avoid the common gastrointestinal side effects related to oral route of administration ${ }^{[26]}$.

The kidneys are particularly vulnerable to toxic substances due to their high blood supply. They receive about $25 \%$ of the cardiac output ${ }^{[27]}$. They eliminate deleterious substances from the body; therefore, NPs in the systemic circulation can be filtered by renal clearance $^{[28]}$. The International Program on Chemical Safety for $\mathrm{TiO}_{2}$ declared that ingested $\mathrm{TiO}_{2}$ is eliminated mainly through urine ${ }^{[29]}$. Thence, the kidney is viewed to be one of the vital organs susceptible to the injurious effects of $\mathrm{TiO}_{2}$.

The histological examination of renal cortex sections of group III revealed various changes, such as apparent congested dilated glomerular capillaries, flattening of the epithelial lining of some tubules, exfoliation and pyknosis of some tubular cells with apparent luminal dilatation and intratubular cell debris.

These results were in accordance with previous histological studies which revealed that nephrotoxic effect is associated with $\mathrm{TiO}_{2}$ exposure ${ }^{[6,7,11]}$. The tubular degeneration was supported by a significant increase in caspase- 3 reaction. Some studies supported this finding and showed that TNPs exposure could induce apoptosis in different types of cells or organs, as the liver, spleen and kidney ${ }^{[7,25]}$.

Apoptosis (programmed cell death) is a complex biological process that is important for regulating cell survival via removal of deteriorated or diseased cells $^{[30]}$. It is usually applied to any kind of cell death mediated by an intracellular death program, regardless of the initiated mechanism ${ }^{[27]}$. Caspase- 3 is a well known marker of apoptosis, which could be activated by both extrinsic and intrinsic apoptotic pathways and consequently lead to breakdown of DNA ${ }^{[31-33]}$.
In present study, group III showed significant increase of desmin immunostaining in the renal glomerulus. The intermediate filament protein (desmin) had been known as an indicator of podocytic injury. The expression was often upregulated in various glomerular diseases in which podocytic injuries were involved ${ }^{[34,35]}$.

Podocyte epithelial dedifferentiation was associated with the induction of mesenchymal markers such as desmin. The increase of transforming growth factor- $\beta 1$ in the damaged kidney might lead to podocytic epithelial dedifferentiation and mesenchymal transition. On the other hand, desmin expression in podocytes is considered as an essential marker for podocyte epithelial-to-mesenchymal transition ${ }^{[36]}$.

In the current study, group III revealed congested dilated glomerular capillaries, mononuclear cell infiltrations and fibrosis between degenerated tubules and renal corpuscles. Recent studies clarified that nanoparticles as TNPs after entry into cells, lead to initiate inflammatory mechanisms, apoptosis and generate the oxygen free radicals which harm the nucleus and mutate DNA, and also alter the functions of cells ${ }^{[7,13]}$. Some authors stated that TNPs increased expression of different cytokines as tumor necrosis factor- $\alpha$, interleukins (ILs) specially IL-6 and IL-8 and chemokines, which are directly chemotactic to leukocytes and other cells which participate in inflammatory reaction and subsequent kidney damage ${ }^{[37]}$. Thus the mononuclear cell infiltrations showed in this group were inflammatory cell infiltrations participating in inflammatory response.

On the other hand, some scientists stated that the leakage of fluid from the tubules causes edema and cellular infiltrations which finally lead to interstitial fibrosis. However, the flattened cells with flattened nuclei observed lining some tubules may be transformed into fibroblasts ${ }^{[6]}$.

Fibroblasts originate mainly within the interstitial tissue through a process called epithelial-mesenchymal transition. The change of tubular epithelial cells into a mesenchymal phenotype is started by disturbance in the balance of local cytokine concentrations. As a consequence to chronic inflammation and persistent injury of the kidney parenchyma, fibroblasts raise their numbers and by secreting large amount of extracellular matrix, disturb normal interstitial architecture of the kidney. Many studies postulated that in renal fibrosis, more than thirty percent of all disease-related, fibroblasts originate from tubular epithelial cells at the site of injury. Fibroblastic proliferation in response to local mitogens commonly resulted in tubulointerstitial nephritis and irreversible renal failure. New therapeutic interventions in renal fibrosis are directed toward 
inhibition of fibroblast formation. This can be done by shifting local cytokine balance in favour of reflection of mesenchymal-epithelial transition ${ }^{[27]}$.

In this study there was a significant increase in the number of brown PCNA positive nuclei in renal tubular cells and PCNA-positive proliferating mononuclear cells in interstitial tissue was seen in group III. PCNA is a marker of cell division and proliferation. PCNA found in cell nucleus and was directly involved in DNA synthesis ${ }^{[38]}$.

Previous studies revealed that the mechanism of action of $\mathrm{TiO}_{2}$ induced nephrotoxic effect was mediated via release of the products of oxidative stress such as different cytokines, reactive oxygen species and at the same time the decrease of cellular antioxidants. These reactive oxygen species of oxidative stress were detrimental and injurious to the cell compounds as lipid, protein and membranes, eventually leading to inactivate structural proteins, enzymes, and ion pumps, increase lipid peroxidation, impairment of cell functions, inflammation, cytolysis, interstitial fibrosis, mutation and damage to DNA and apoptosis ${ }^{[4,13]}$.

Moreover, Masoud et al. ${ }^{[39]}$ stated that, in the presence of TNPs, the nicotinamide adinine dinucleotide phosphate (NADPH) oxidase produces more superoxide ions leading to more oxidative stress.

The histological examination of group IV of this study showed marked amelioration of various changes produced by TNPs. Most of the glomeruli were more or less as that of the control. A significant decrease of collagen fibers, desmin, PCNA and caspase- 3 reaction were detected. These results were in agreement with previous investigators who reported that lycopene has a protective effect ${ }^{[20,40,41]}$.

\section{CONCLUSION}

TNPs have a nephrotoxic effect at the level of the dose given in this study. So, it is convenient to decrease the exposure to these particles as possible.

Lycopene which is a potent antioxidant carotenoid has a protective role against TNPs nephrotoxicity. Subsequently, workers' exposed to TNPs are advised to intake natural carotenoids.

\section{CONFLICT OF INTEREST}

There are no conflicts of interest.

\section{REFERENCES}

1. Smith SW. Nanotoxicology. In: Hoffman RS, Howland MA, Lewin NA, Nelson LS, Goldfrank LR, editors. Goldfrank's toxicologic emergencies, $10^{\text {th }}$ ed. Ch. 129, McGraw Hill education, New York. 2015; $1643-1664$.

2. Adikwu E, Deo O, Geoffrey OP, Enimeya DA. Lead organ and tissue toxicity: Roles of mitigating agents (Part 1). British Journal of Pharmacology and Toxicology 2013; 4(6): 232 -240.

3. Dobrzýnska MM, Gajowik A, Radzikowska J, Lankoff A, Dŭsinská M, Kruszewski M. Genotoxicity of silver and titanium dioxide nanoparticles in bone marrow cells of rats in vivo. Toxicology 2014; 315:86-91.

4. Oberdörster $G$, Kane AB, Klaper RD, Hurt RH. Nanotoxicology. In: Casarett and Doull's toxicology, the basic science of poisons, Klaassen CD editor, $8^{\text {th }}$ ed.Ch 28, McGraw-Hill Education, New York, Chicago, San Francisco, Lisbon, London, 2013; pp 1189- 1229.

5. Driessen MD,Mues S, Vennemann A,Hellack B, Bannuscher A,Vimalakanthan V, Riebeling C, Ossig R, Wiemann M, Schnekenburger J, Kuhlbusch TA, Renard B, Luch A, Haase A. Proteomic analysis of protein carbonylation: a useful tool to unravel nanoparticle toxicity mechanisms. Part Fibre Toxicol 2015; 2 (12):36.

6. Helmy AM, Sharaf-El-Din NA, Abd-El-Moneim RA, Rostom DR. Histological study of the renal cortical proximal and distal tubules in adult male albino rats following prolonged administration of titanium dioxide nanoparticles and the possible protective role of 1-carnosine. The Egyptian Journal of Histology 2015; 38:126 -142.

7. Fartkhooni FM, Noori A, Mohammadi A. Effects of titanium dioxide nanoparticles toxicity on the kidney of male rats. International Journal of Life Sciences 2016; 10 (1): $65-69$.

8. Shakeel M, Jabeen F, Shabbir S, Asghar MS, Khan MS, Chaudhry AS. Toxicity of nano-titanium dioxide $\left(\mathrm{TiO}_{2}-\mathrm{NP}\right)$ through various routes of exposure: a review. Biol Trace Elem Res 2016; 172(1):1- 36.

9. Ultrafine titanium dioxide particles in the absence of photoactivation can induce oxidative damage to human bronchial epithelial cells. Gurr JR, Wang 
ASS , Chenb CH, Jan KY. Toxicology 2005; (213): 66-73.

10. Xu J, Shi H, Ruth M, Yu H, Lazar L, Zou B, Yang C, Wu A, Zhao J (2013) Acute toxicity of intravenously administered titanium dioxide nanoparticles in mice. PLoS ONE 2013; 8(8): e70618, 6 pages.

11. Attia HF, Soliman MM, Abdel-Rahman GH, Nassan MA, Ismail SA, Farouk M, Solcan C. Hepatoprotective effect of $\mathrm{N}$-acetylcystiene on the toxic hazards of titanium dioxide nanoparticles. American Journal of Pharmacology and Toxicology 2013, 8 (4): 141- 147.

12. Ben Younes NR, Amara S, Mrad I, Ben-Slama I et al. Subacute toxicity of titanium dioxide $\left(\mathrm{TiO}_{2}\right)$ nanoparticles in male rats: emotional behavior and pathophysiological examination. Environ Sci Pollut Res 2015; 22:8728-8737.

13. Grande F, Tucci P. Titanium dioxide nanoparticles: a risk for human health? Mini Rev Med Chem 2016; 16(9):762- 769 .

14. El-Mahalaway AM, Selim AA, Mahboub FAR. The potential protective effect of propolis on experimentally induced hepatitis in adult male albino rats. Histological and immunohistochemical study. Journal of Histology \& Histopathology 2015; 2, (14): $1-14$.

15. Daniel EE, Mohammed A, Tanko Y, Ahmed A. Effect of lycopene on altered kidney antioxidant enzymes activity and functions in streptozotocininduced diabetic wistar rats. Cell Biology 2015; 3, (1):1- 13 .

16. Sweetman SC. Martindale, The complete drug reference. $37^{\text {th }}$ ed., Pharmaceutical Press, UK and USA. 2011; P 2335.

17. Sharma S and Vijaya P: Ameliorating potential of lycopene against cadmium toxicity in kidney of albino mice. International Journal of Advanced Research 2015; 3 (2): 766- 770.

18. Yildiz M, Sandikci M. Changes in rat ovary with experimentally induced diabetes and the effects of lycopene on those changes. Rom J Morphol Embryol 2016;57(2 Suppl):703- 713.

19. El-Sayed EM, Fouda EE, Mansour AM, Elazab AH. Protective Effect of lycopene against carbon tetrachloride-induced hepatic damage in rats. Int $\mathrm{J}$ Pharma Sci 2015; 5(1): 875- 881 .
20. Pandir D, Unal B, Bas H . Lycopene protects the diabetic rat kidney against oxidative stressmediated oxidative damage induced by furan. Arch Biol Technol 2016;59: e16150794. 1- 12.

21. Alazouny ZM, Mohamed EM, Ahmed GA. Effect of cyclosporine A on the structure of adult albino rat testis and the role of lycopene supplementation: a histological and immunohistochemical study. The Egyptian Journal of Histology 2014; 37:292 -303.

22. Bancroft JD, Layton C. The hematoxylin and eosin, connective and mesenchymal tissues with their stains. In: Suvarna SK, Layton C and Bancroft JD, editors. Bancroft's theory and practice of histological techniques. $7^{\text {th }}$ edition. Churchill Livingstone: Philadelphia, 2013; 173- 212.

23. El-Azab NEE, Salem MY:Are titanium dioxide nanoparticles toxic to the cerebral cortex of rats? A histological and immunohistochemical study. The Egyptian Journal of Histology 2015; 38: $573-581$.

24. Armand L, Tarantini A, Beal D, Biola-Clier M, Bobyk L, Sorieul S, Pernet-Gallay K, MarieDesvergne C, Lynch I, Herlin-Boime N, Carriere M. Long-term exposure of A549 cells to titanium dioxide nanoparticles induces DNA damage and sensitizes cells towards genotoxic agents. Nanotoxicology 2016;10 (7):913- 923.

25. Mohamed SH, Sayed HA. Effect of titanium dioxide nanoparticles on the liver and renal cortex of albino rats. An electron microscopic study. The Egyptian Journal of Histology 2013; 36:389- 399.

26. Nebendahl K. Routes of administration. In: Krinke GJ, editor. The handbook of experimental animals: the laboratory rat, $1^{\text {st }}$ ed. Ch 24 . Academic Press, New York 2000; pp 463- 483.

27. Pawlina W. Histology a text and atlas with correlated cell and molecular biology, $7^{\text {th }} \mathrm{ed}$. Wolters Kluwer, Philadelphia, Baltimore, New York, London, 2016; pp 698 -699, pp 91- 94 and P.720.

28. Pujalté I, Passagne I, Brouillaud B, Tréguer M, Durand E, Ohayon-Courtès C, L'Azou B. Cytotoxicity and oxidative stress induced by different metallic nanoparticles on human kidney cells. Part Fibre Toxicol 2011; 8:10. 
29. Food and Agriculture Organization of the Unitated Nations. 67 $7^{\text {th }}$ JECFA - Chemical and Technical Assessment (CTA) of Titanium dioxide (cited: 2014 jan 3).

30. Kuranaga E: Beyond apoptosis: caspase regulatory mechanisms and functions in vivo. Genes Cells 2012; 17:83-97.

31. Dai C, Tang S, Deng S, Zhang S, Zhou Y, Velkov T, Li J, Xiao X. Lycopene attenuates colistin-induced nephrotoxicity in mice via activation of the Nrf2/ HO-1 pathway. Antimicrob Agents Chemother 2015; 59: $579-585$.

32. Stayer DS, Rubin E, Saffitz JE, Schiller AL. Rubin's pathology, clinicopathological foundations of medicine. $7^{\text {th }}$ ed. Woters Kluwer, Philadelphia, Baltimore, New York, London 2015; pp 40 -53.

33. Kumar V, Abbas AK, Aster JC. Editors, Robbin's basic pathology. $9^{\text {th }}$ ed., Elsevier Saunders Company, Philadelphia 2013; pp 18 -22.

34. Zou J, Yaoita E, Watanabe Y, Yoshida Y, Nameta M, Li H. Upregulation of nestin, vimentin and desmin in rat podocytes in response to injury. Virchows Arch 2006; 448: 485- 492.

35. Qin W, Xu Z, Lu Y, Zeng C, Zheng C. Mixed organic solvents induce renal injury in rats. PLoS. One 2012; 7: e45873, 11 pages.

36. Li Y, Kang YS, Dai C, Kiss LP, Wen X, Liu Y. Epithelial-to-mesenchymal transition is a po $\neg$ tential pathway leading to podocyte dysfunction and proteinuria. Am J Pathol 2008; 172: $299-308$.

37. Kumar S, Meena R, Paulraj R. Role of macrophage (M1 and M2) in titanium-dioxide nanoparticleinduced oxidative stress and inflammatory response in rat. Appl Biochem Biotechnol 2016; 180(7):1257- 1275.

38. Hegazy R, Salama A, Mansour D, Hassan A.: Renoprotective Effect of Lactoferrin against Chromium-Induced Acute Kidney Injury in Rats:
Involvement of IL-18 and IGF-1 Inhibition. PLoS ONE. 2016; 11(3): e0151486. 1- 18.

39. Masoud R, Bizouarn T, Trepout S, Wien F, Baciou L, Marco S, Levin CH. Titanium dioxide nanoparticles increase superoxide anion production by acting on NADPH oxidase. PLoS ONE 2015; 10(12): e0144829, 17 pages.

40. Li W, Wang G, Lu X, Jiang Y, Xu L, Zhao X. Lycopene ameliorates renal function in rats with streptozotocin-induced diabetes. Int J Clin Exp Pathol 2014;7(8):5008 -5015.

41. Kaya C, Karabulut R, Turkyilmaz Z, Sonnez K, Kuluk G. Lycopene has reduced renal damage histopathologically and biochemically in experimental renal ischemia-reperfusion injury. Journal Renal failure 2015; 37 (8): 1390- 1395.

42. Yildiz M, Sandikci M. Changes in rat ovary with experimentally induced diabetes and the effects of lycopene on those changes. Rom J Morphol Embryol 2016;57(2 Suppl):703- 713.

43. Abd El-Haleem MR, Abass MA. Effect of bisphenol $\mathrm{A}$ on the myocardium of adult male albino rats and the possible role of lycopene: a histological and biochemical study. The Egyptian Journal of Histology 2012; 35:326 -339.

44. Palabiyik SS, Erkekoglu P, Zeybek ND, Kizilgun M, Baydar DE, Sahin G, Giray BK. Protective effect of lycopene against ochratoxin A induced renal oxidative stress and apoptosis in rats. Exp Toxicol Pathol 2013; 65(6):853 -861.

45. Bayomy NA, Elbakary RH, Ibrahim MA, Abdelaziz EZ. Effect of lycopene and rosmarinic acid on gentamicin induced renal cortical oxidative stress, apoptosis and autophagy in adult male albino rat. Anat Rec (Hoboken) 2016 Nov 24 (in press). 
الملخص العربى

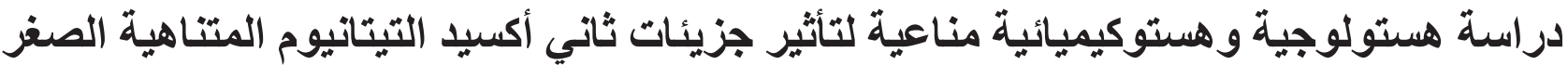

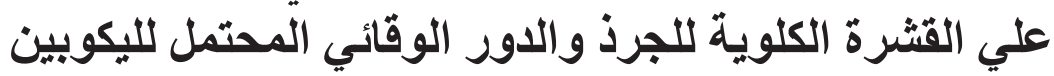

\section{زينب محمد الطيب1 وعبير مصطقي المحلاوي² وميسرة محمود سالم33.}

\author{
1قسم الأنسجة وبيولوجيا الخلية ـ كلية الطب - جامعة حلوان ـ مصر \\ 2,3قسم الأنسجة وبيولوجيا الخلية ـ كلية الطب - جامعة بنها ـ مصر
}

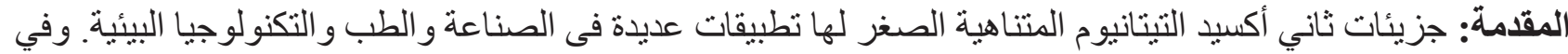

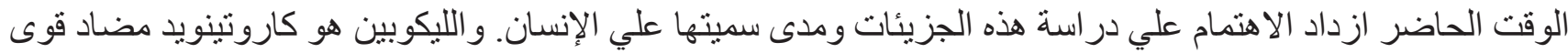
للأكسدة.

الهرف: معرفة وتقييم تأثير جزيئات ثاني أكسيد التيتانيوم المتتاهية الصغر علي القترة الكلوية للجرذان و الدور الوقائي المحتمل لليكوبين. مواد وطرق البحث: تضمنت الدراسة عدد خمس وأربعين من ذكور الجرذان البالغة وقد قسمت إلي أربع مجمو عات كالتالي:

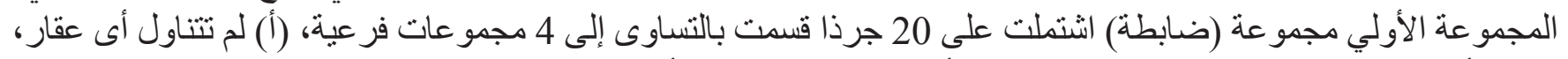

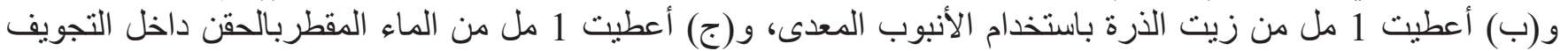

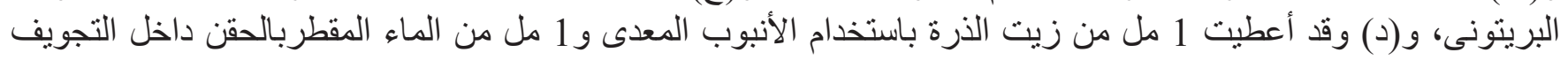

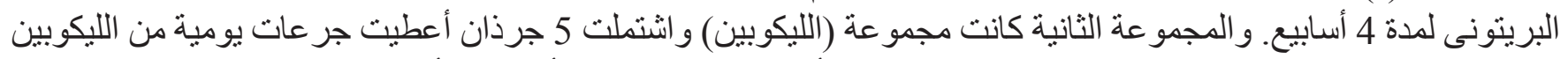

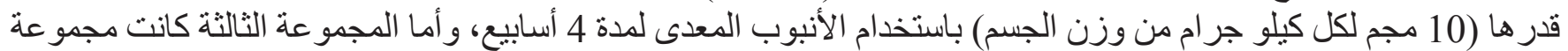

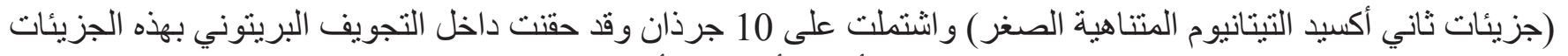

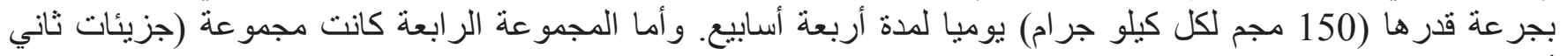

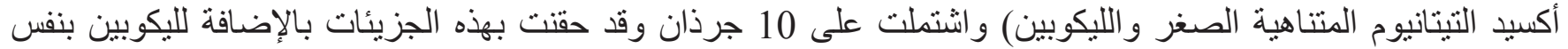

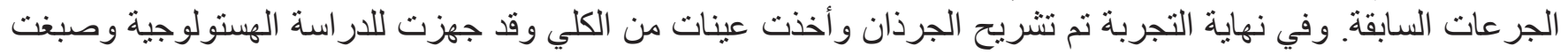

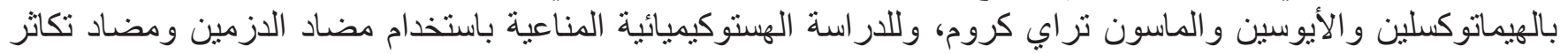

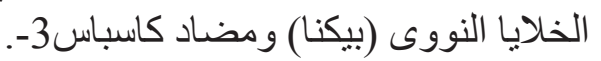

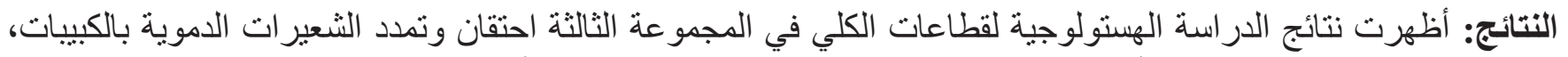

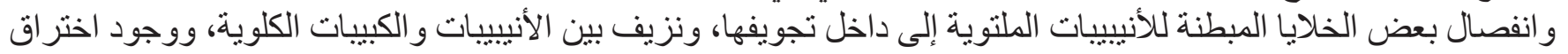

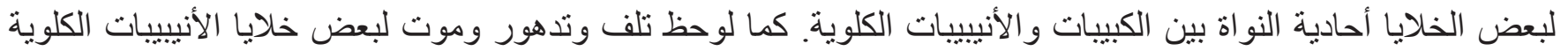

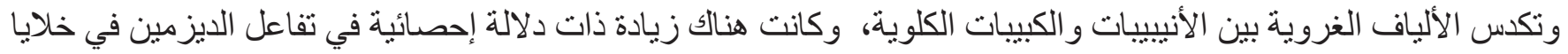

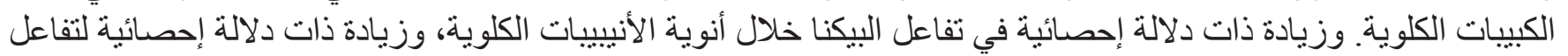

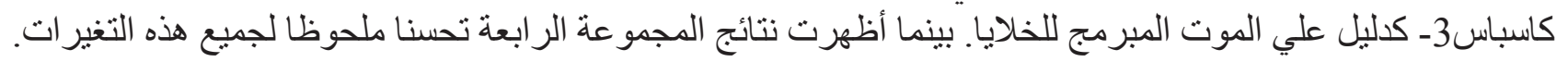

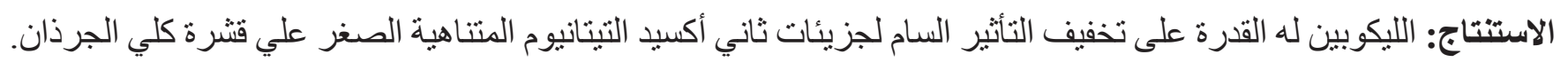

